\title{
The Kliniko-Hygienic Description of a Case of Vibrating Illness at the Driver of the Forge Sharzhir-Car
}

\author{
Bazarova EL ${ }^{* 1,2}$, Roslaya NA ${ }^{2}$, Osherov IS ${ }^{1}$ and Nasybullina GM ${ }^{2}$ \\ ${ }^{1}$ Tirus Medical Unit, Russia \\ ${ }^{2}$ The Ural state medical university Ministry of Health of Russia, Russia \\ *Corresponding author: Bazarova EL, Tirus Medical Unit, Ekaterinburg, Russia
}

\begin{tabular}{|c|c|}
\hline ARTICLE INFO & ABSTRACT \\
\hline Received: 豐 February 04, 2019 & Citation: Bazarova EL, Roslaya NA, Osherov IS, Nasybullina GM. The Kliniko-Hygienic De- \\
\hline Published: 彗 February 14, 2019 & $\begin{array}{l}\text { scription of a Case of Vibrating Illness at the Driver of the Forge Sharzhir-Car. Biomed J Sci } \\
\text { \& Tech Res 14(4)-2019. BJSTR. MS.ID.002576. }\end{array}$ \\
\hline
\end{tabular}

\section{Opinion}

Vibration is one of the most widespread production factors of risk. At manufacture modernization on modern semiautomated the enterprises cases of vibrating illness are individual. In this connection their clinic-hygienic analysis and comparison of levels of vibration to a clinical picture is of interest. To the smith on presses forge-pressbook shops of the metallurgical enterprise at the age of 42 years at the experience of work the smith of 19 years in the regional center of professional illnesses of Ekaterinburg had been established the diagnosis: $\mathrm{T}$ 75.2. Vibrating illness of the first degree: a syndrome vegetation-touch polyneuropathy of the top extremity. The patient was disturbed by pains and paranesthesia in hands in rest, it is more at night, sensitivity infringements, vegetovascular frustration, decrease in endurance of muscles to static effort.

In forge branch it is made forging of half-finished products from titanic, steel and aluminum alloys on vertical hydraulic press. As a part of a brigade of smiths performed work of the machinist (the operator, the driver) the forge sharzhir-car (the rail forge manipulator). Duties of the machinist of the manipulator include loading by means of the manipulator of ingots or preparations into the heating furnace for heating, an unloading hot ingots and preparations from the furnace, their giving on a press for forging, deduction and preparation orientation during time of forging, transportation of the forged preparations by means of the manipulator on the refrigerator or in the heating furnace for the further heating and forging. Manipulator movement is carried out on rails. The workplace of the machinist is directly on the manipulator. A cabin of the manipulator of open type, without vibrio - and sound insulation.
Time of influence of local vibration at management of the manipulator averages $60 \%$ from duration of a labor shift. Smiths are provided with special clothes and individual defense means. On a site there is a rest room. Working conditions are characterized by influence of various factors by the nature (physical, chemical, weight and intensity of labor process) and the combined influences of harmful factors (the general technological, transport no-technological and local vibration, the combined influence of harmful substances, including sharp, allergenic, cancerogenic, irritating, actions; aerosols mainly fibrogenic actions, electromagnetic fields from industrial computers and electric furnaces). Sources of local vibration are control levers the manipulator. The equivalent corrected level vibration acceleration is equal $134 \mathrm{~dB}$ at maximum permissible level $126 \mathrm{~dB}$ that corresponds to high professional risk. A source of the general transport no-technological vibration is the forge manipulator moving on rails. The equivalent corrected levels speed of vibration of transport no-technological vibration made for a direction of axes X / Y / Z 91 / 88 / 96dB at norm 101dB (admissible working conditions). A source of the general technological vibration is the hydraulic press. The equivalent corrected levels speed of vibration - 113 / $111 / 105 \mathrm{~dB}$ at at norm 92dB (very high risk).

Accompanying harmful production factors are noise (equivalent levels of a sound 85-88 dB at norm taking into account weight of work $70 \mathrm{~dB}$; risk average-high); a heating up microclimate (air temperatures during the warm period of year $28-31^{\circ} \mathrm{C}$ at norm 15 $20^{\circ} \mathrm{C}$, during the cold period of year: $24-25^{\circ} \mathrm{C}$ at norm $13-20^{\circ} \mathrm{C}$; THC 
- an index $18,2-20,1^{\circ} \mathrm{C}$ at ПДУ $18-21,8^{\circ} \mathrm{C}$; intensity thermal irradiations: $440-3500 \mathrm{Vt} / \mathrm{m} 2$ at norm $140 \mathrm{Vt} / \mathrm{m} 2$; risk from small to very high). Concentration of a dust and harmful substances in air did not exceed maximum permissible. Weight of work is defined by the efforts applied on control levers by the manipulator, and weight of cargo at lifting and moving demountable capture of cargoes adaptations in the course of performance slinger works. Weight of moved cargo - $7 \mathrm{~kg}$ at admissible to $30 \mathrm{~kg}$ (admissible working conditions).

Leading indicators of intensity of labor process are high degree of responsibility for results of work, duration of the concentrated supervision, visual pressure at work on the computer, pressure of hearing at work in the conditions of noise, shift work with night shifts. Working conditions on intensity of work are carried to the admissible. An integrated estimation of working conditions, according to Management P 2.2.2006-05: harmful working conditions of 3-4 degrees (classes 3.3-3.4) that corresponds to high and very high professional risk. At reconstruction of forge branch forge-pressbook shops workplaces of smiths on rail manipulators as unhealthy are liquidated and replaced with diesel auto-loaders of "Glama" with the closed cabin and isolation from vibration.

\section{ISSN: 2574-1241}

DOI: 10.26717.BJSTR.2019.14.002576

Bazarova EL. Biomed J Sci \& Tech Res

(C) This work is licensed under Creative

Submission Link: https://biomedres.us/submit-manuscript.php

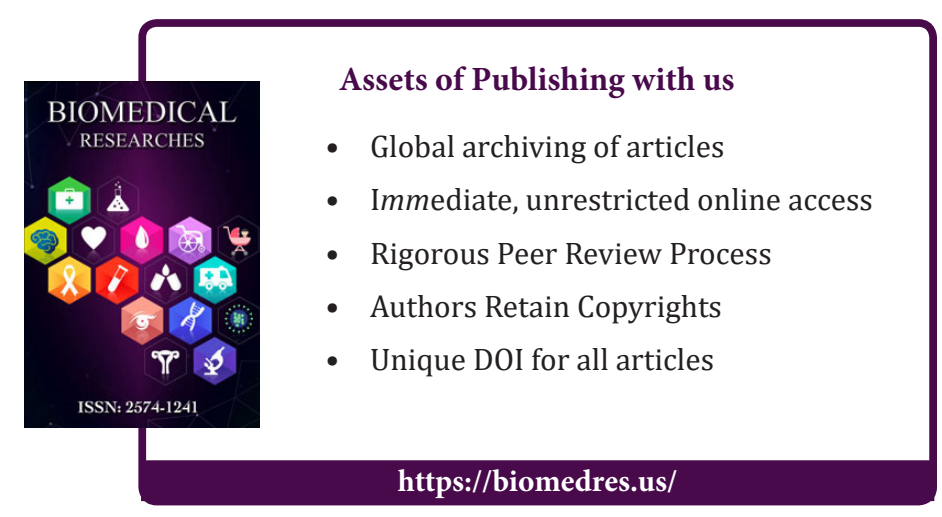

